\title{
Clinico-pathological study of benign soft tissue tumors: a study from tertiary teaching hospital
}

\author{
Deepak MB ${ }^{1 *}$, Suchitha $S^{2}$, Manjunath $G^{3}$, Ira Bharadwaj ${ }^{4}$ \\ ${ }^{1}$ Dr Deepak MB, Assistant Professor, Department of Pathology, Karuna Medical College, Chittur, Kerala, ${ }^{2}$ Dr Suchitha \\ S, Associate Professor, Department of Pathology, JSS Medical College, Mysore, Karnataka, ${ }^{3}$ Dr Manjunath GV, \\ Professor and HOD, Department of Pathology, JSS Medical College, Mysore, Karnataka, ${ }^{4}$ Dr Ira Bharadwaj, Professor \\ and HOD, Department of Pathology, Karuna Medical College, Chittur, Kerala, India.
}

Address for Correspondence: Dr Deepak MB, Email: deepakmb.skt@gmail.com

\begin{abstract}
Background: Aim of the study was to analyze the histopathological findings in various benign soft tissue tumors and to study its frequency distribution in relation to age, gender and anatomical site. Material and Method: Total of 250 cases of soft tissue lesions were analyzed retrospectively and prospectively in a period 2.5 years during June 2009 to Dec 2011. In addition to routine Haematoxylin and Eosin stained sections of all the specimens, special stains with immunohistochemical markers were done wherever necessary. Age and sex incidence, site of lesion, clinical features, gross and microscopic appearance were carefully studied. Result: Of 250 lesions analyzed, 213 (185.2\%) were benign soft tissue tumors. Overall a male predominance was seen with $57.4 \%$ in males. Majority of the benign tumors occurred in third decade $(21 \%)$. The most common site of occurrence was head and neck (38\%). On gross examination 160 (75\%) cases measured less than $5 \mathrm{cms}$. Lipoma was the most common benign soft tissue tumor (68 cases, $31.9 \%$ ) followed by capillary hemangioma (28 cases, 13.1\%). Conclusion: The large majority of soft tissue tumors are benign with a very high cure rate after surgical excision. Aggressive benign myxoid soft tissue tumors require wide surgical excision and close follow up. The diagnosis and management of benign soft tissue tumors require a team perspective consisting of clinical, radiological and pathological correlation.
\end{abstract}

Key words: Soft tissue tumors; Benign; Aggressive angiomyxoma; Adipocytic; Granular cell tumor.

\section{Introduction}

Soft tissue is a non-epithelial extra skeletal tissue of the body wherein reticuloendothelial system, glia and supporting tissue of parenchymal organs are excluded. It is constituted by voluntary muscles, fat, fibrous tissue and supplying blood vessels. Peripheral nervous system is included under soft tissue by convention. They are derived principally from embryonic mesoderm with some contribution from neuroectoderm. Frequency of neoplastic process arising in tissues of mesenchymal origin is far less compared with tumors of ectodermal and endodermal origin [1,2].

Soft tissue tumors (STT) are rare neoplasms. Benign tumors occur with an annual incidence of 300 per 1 lakh population and outnumber malignant tumors by a margin of approximately 100:1[3,4]. Majority of benign

Manuscript received: $5^{\text {th }}$ October 2016

Reviewed: $15^{\text {th }}$ October 2016

Author Corrected: $28^{\text {th }}$ October 2016

Accepted for Publication: $15^{\text {th }}$ November 2016 tumors occur during second, third and fourth decades of life [5]. Patients with suspected soft tissue neoplasms commonly present with a painless mass, but in up to one-third of cases pain is reported [6]. An accurate diagnosis is dependent on thorough history, clinical examination, organ imaging and histopathological study of core biopsy or resected specimen. In cases where morphological features are often not sufficient to arrive at specific diagnosis, other tests particularly immunohisto chemical markers and cytogenetic evaluation are essential diagnostic aids $[7,8]$.

\section{Objectives}

1. To study the frequency distribution of benign soft tissue tumors in relation to age, gender and anatomical site.

2. To compare the histological findings of benign soft tissue tumors with other similar studies. 


\section{Materials and Methods}

The soft tissue tumors received at the histopathology unit of Department of Pathology, JSS Hospital, Mysore, were studied for a period of two and a half years. Clinical history of all the cases was collected in pretested proforma meeting the objectives of the study.

A detailed gross examination of the soft tissue specimen was performed to record the size, shape, colour, consistency and distance from the deep resected margins. The specimens were preserved in $10 \%$ formalin and allowed to fix for $24 \mathrm{hrs}$. The haematoxylin and eosin stained sections of all the specimens obtained by routine processing and paraffin embedding were studied to evaluate histopathological features.

Special stains such as periodic acid Schiff (PAS) and reticulin with immunohistochemical markers were done, wherever necessary. The classification adopted for the present study is based on the WHO classification of soft tissue tumors (2002) [9].

\section{Results}

Out of the total 250 specimens received, $213(85.2 \%)$ of soft tissue tumors were benign, whereas $7(2.8 \%)$ were intermediate and $30(12 \%)$ were malignant. The distribution of benign tumors was highest in adipocytic (35.2\%), vascular tissue $(30.5 \%)$ followed by neural $(20.1 \%)$. (Table 1) Benign STT's were encountered more in males than females with male to female ratio of 1.4:1. (Table 2) The youngest patient in the present study was 2 years while the oldest was 89 years old. Majority of the benign tumors occurred in the third decade (Table 3).

Table-1: Distribution of benign soft tissue tumors.

\begin{tabular}{|c|c|c|c|}
\hline \multirow{2}{*}{ Sl. No. } & \multirow{2}{*}{ Tumors } & \multicolumn{2}{|c|}{ Benign } \\
\cline { 2 - 4 } & & No. of cases (n=213) & \% \\
\hline 1. & Adipocytic & 75 & 6.6 \\
\hline 2. & Fibroblastic/myofibroblastic & 14 & 3.2 \\
\hline 3. & Fibrohistiocytic & 5 & 2.4 \\
\hline 4. & Smooth muscle & 1 & 0.5 \\
\hline 5. & Pericytic & 65 & 30.5 \\
\hline 6. & Vascular & 43 & 20.2 \\
\hline 7. & Neural & 3 & 1.4 \\
\hline 8. & Uncertain differentiation & 7 & \\
\hline
\end{tabular}

Table-2: Gender distribution of benign soft tissue tumors.

\begin{tabular}{|c|c|c|c|c|c|c|}
\hline Sl. No. & Tumors & Males & \% & Females & \% & Total \\
\hline 1 & Adipocytic & 46 & 21.6 & 29 & 13.6 & 75 \\
\hline 2 & $\begin{array}{c}\text { Fibroblastic/ } \\
\text { myofibroblastic }\end{array}$ & 11 & 5.2 & 3 & 1.4 & 14 \\
\hline 3 & Fibrohistiocytic & 6 & 2.8 & 1 & 0.5 & 7 \\
\hline 4 & Smooth muscle & - & - & 5 & 2.4 & 5 \\
\hline 5 & Pericytic & 1 & 0.5 & - & - & 1 \\
\hline 6 & Vascular & 37 & 17.4 & 28 & 13 & 65 \\
\hline 7 & Neural & 21 & 9.9 & 22 & 10.3 & 43 \\
\hline 8 & Uncertain differentiation & - & - & 3 & 1.4 & 3 \\
\hline
\end{tabular}


Table-3: Age distribution of benign soft tissue tumors.

\begin{tabular}{|c|c|c|c|c|c|c|c|c|c|c|}
\hline $\begin{array}{l}\text { Sl. } \\
\text { No. }\end{array}$ & Tumors type & $0-9$ & $10-19$ & $20-29$ & $30-39$ & $40-49$ & $50-59$ & $60-69$ & $70-79$ & $80-89$ \\
\hline 1 & Adipocytic & 1 & 2 & 12 & 10 & 10 & 17 & 14 & 6 & 3 \\
\hline 2 & $\begin{array}{c}\text { Fibroblastic/ } \\
\text { myofibroblastic }\end{array}$ & - & 2 & 3 & 3 & 2 & 1 & 1 & - & 1 \\
\hline 3 & Fibrohistiocytic & - & - & 2 & 3 & - & 1 & - & 1 & - \\
\hline 4 & Smooth muscle & - & 1 & 3 & 1 & - & - & - & - & - \\
\hline 5 & Vascular & 11 & 12 & 15 & 6 & 6 & 8 & 4 & 3 & 1 \\
\hline 6 & Pericytic & - & - & - & - & - & 1 & - & - & - \\
\hline 7 & Neural & - & 7 & 10 & 6 & 7 & 4 & 7 & 2 & -- \\
\hline 8 & $\begin{array}{c}\text { Uncertain } \\
\text { differentiation }\end{array}$ & - & - & - & - & 2 & - & 1 & - & - \\
\hline & Total & 12 & 24 & 45 & 29 & 27 & 32 & 27 & 12 & 5 \\
\hline
\end{tabular}

Soft tissue tumors occurred all over the body true to its vast distribution. Majority of benign soft tissue tumors showed predilection for head and neck accounting for $38 \%$ followed by trunk accounting for $19 \%$. (Table 4)

Table-4: Anatomical sites of benign soft tissue tumors

\begin{tabular}{|c|c|c|c|c|c|c|c|}
\hline \multirow{3}{*}{ Sl. No. } & \multirow{3}{*}{ Tumor type } & \multicolumn{4}{|c|}{ Extremities } & \multirow{3}{*}{ Trunk } & \multirow{3}{*}{$\begin{array}{c}\text { Head and } \\
\text { neck }\end{array}$} \\
\hline & & \multicolumn{2}{|c|}{ Upper } & \multicolumn{2}{|c|}{ Lower } & & \\
\hline & & Prox & Dist & Prox & Dist & & \\
\hline 1. & Adipocytic & 15 & 5 & 10 & 2 & 26 & 17 \\
\hline 2. & Fibroblastic/Myofibroblastic & 2 & 2 & - & 1 & 2 & 7 \\
\hline 3. & Fibrohistiocytic & 1 & 6 & - & - & - & - \\
\hline 4. & Smooth muscle & - & - & 4 & - & - & 1 \\
\hline 5. & Vascular & 1 & 3 & 6 & 6 & 8 & 41 \\
\hline 6. & Pericytic & - & - & - & 1 & - & - \\
\hline 7. & Neural & 6 & 6 & 4 & 4 & 8 & 15 \\
\hline 8. & Uncertain differentiation & - & - & 3 & - & - & - \\
\hline & Total & 25 & 22 & 26 & 15 & 44 & 81 \\
\hline
\end{tabular}

On gross examination, majority of the benign tumors (75\%) were well circumscribed measuring less than $5 \mathrm{cms}$. Microscopically, all soft tissue tumors were histologically typed following 2002 histological classification of soft tissue tumors recognized by WHO. The various histological subtypes of different tumor groups encountered are discussed under individual tumors. The commonest of adipose tumors were lipomas followed by fibrolipomas with male preponderance and predilection for extremities. (Table 5a) Microscopically, lipomas were characterized by mature adipocytes of varying size and shape with small eccentric nuclei. Angiolipoma consisted of mature adipocytes and capillaries, some of which contained microthrombi. Pleomorphic lipoma consisted of mature adipocytes admixed with multinucleated stroma cells, often having floret-like nuclei. Fibrolipoma consisted of mature adipose tissue of varying sizes amidst fibrous tissue.

Table-5 (a): Age, gender, site and histological subtypes of adipocytic tumors.

\begin{tabular}{|c|c|c|c|c|c|}
\hline Sl. No. & Histological type & $\begin{array}{c}\text { No. of cases (\% of } \\
\text { benign tumors) }\end{array}$ & $\begin{array}{c}\text { Age in yrs } \\
\text { (Range) }\end{array}$ & $\begin{array}{c}\text { Sex } \\
\text { M/F }\end{array}$ & Common site \\
\hline 1. & Lipoma & $68(31.9 \%)$ & $5-80$ & $38 / 30$ & Trunk \\
\hline 2. & Fibrolipoma & $4(1.9 \%)$ & $28-60$ & $4 /--$ & Head \& neck \\
\hline 3. & Pleomorphic lipoma & $2(0.9 \%)$ & $62-70$ & $2 /--$ & Head, extremity \\
\hline 4. & Angiolipoma & $1(0.5 \%)$ & 41 & $--/ 1$ & Extremity \\
\hline & Total & $75(35.2 \%)$ & & $44 / 31$ & \\
\hline
\end{tabular}


Research Article

The commonest benign fibrous tumor was fibroma (5 cases, 2.3\%), which occurred, commonly in the older age group with predilection for trunk. There was only one case of solitary myofibroma, proliferative fasciitis and proliferative myositis and all of them occurred in males. There were four cases of angiofibroma and all of them occurred in males with predilection for head and neck (Table 5b).

Table-5 (b): Age, gender, site and histological subtypes of fibro/myofibroblastic tumors

\begin{tabular}{|c|c|c|c|c|c|}
\hline Sl. No. & Histological type & $\begin{array}{c}\text { No. of cases (\% of } \\
\text { benign tumors) }\end{array}$ & $\begin{array}{c}\text { Age in yrs } \\
(\text { Range) }\end{array}$ & $\begin{array}{c}\text { Sex } \\
\mathbf{M} / \mathbf{F}\end{array}$ & Common site \\
\hline 1. & Fibroma & $5(2.3 \%)$ & $33-80$ & $3 / 2$ & Trunk \\
\hline 2. & Collagenous fibroma & $2(0.9 \%)$ & $50-54$ & $2 /--$ & Extremity \\
\hline 3. & Angiofibroma & $4(1.9 \%)$ & $17-35$ & $4 /--$ & Head and neck \\
\hline 4. & Solitary myofibroma & $1(0.5 \%)$ & 17 & $1 /--$ & Head and neck \\
\hline 5. & Proliferative fasciitis & $1(0.5 \%)$ & 20 & $1 /--$ & Extremity \\
\hline 6. & Proliferative myositis & $1(0.5 \%)$ & 63 & $1 /--$ & Head and neck \\
\hline & Total & $\mathbf{1 4}(\mathbf{6 . 6 \%})$ & & $\mathbf{1 2 / 2}$ & $\mathbf{6 : 1}$ \\
\end{tabular}

Microscopically fibromas were characterized by circumscribed nodule, showing paucicellular spindle fibroblasts in a collagenous stroma with scattered vascular channels. Solitary myofibroma consists of primitive spindle cells with haemangiopericytoma-like blood vessels. Collagenous fibroma was characterized by hypocellular regions with widely spaced spindled and stellate-shaped cells embedded in a collagenous background. Proliferative fasciitis was characterized by sheets of plump fibroblastic spindle cells with scattered ganglion like cells. Proliferative myositis consisted of plump fibroblastic spindle cells and ganglion like cells infiltrating between individual muscle fibres in a check board pattern. Angiofibroma consisted of dense fibrocollagenous tissue with interspersed vascular channels of varying calibers. Bland spindled and stellate-shaped fibroblasts in a fibromyxoid background were also noted [Figure 1].

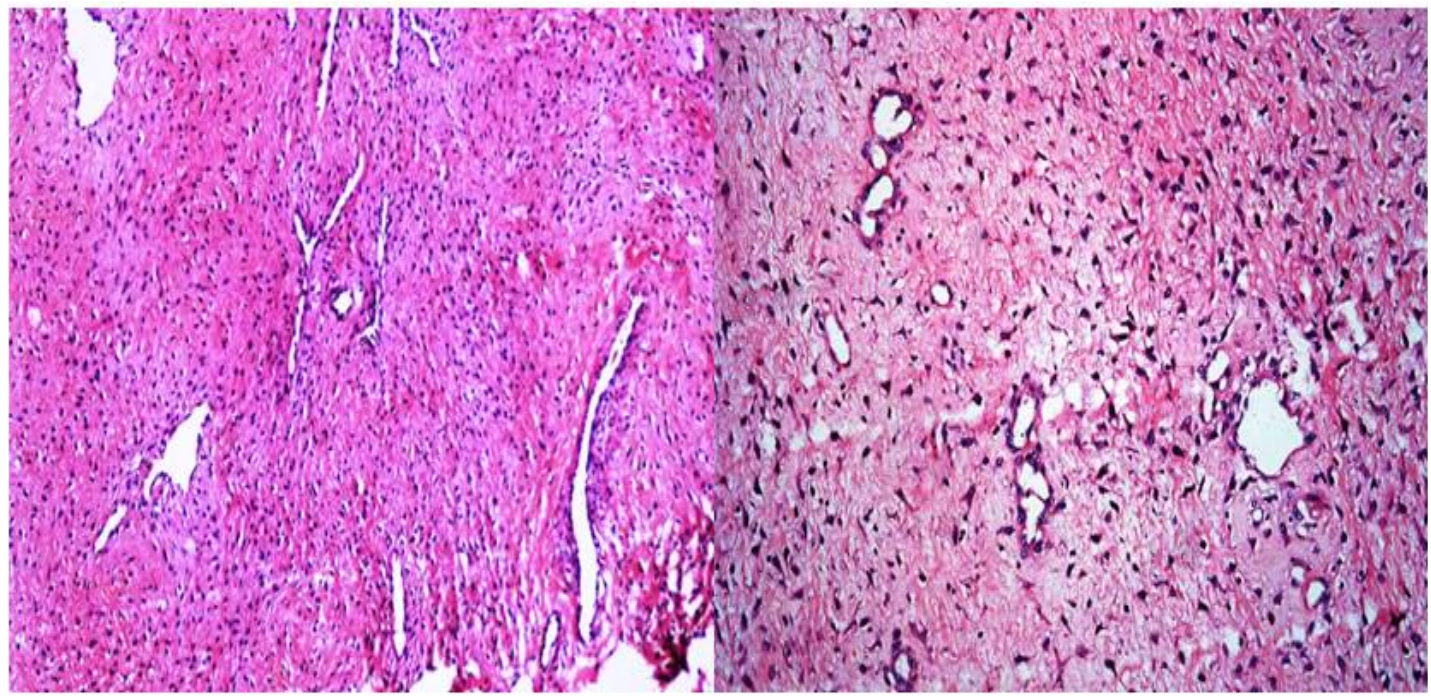

Fig la: Angiofibroma- Dense fibrocollagenous tissue with interspersed vascular channels of varying caliber $(\mathrm{H} \& \mathrm{E}, 10 \mathrm{x})$; Fig lb: Bland spindled and stellate-shaped fibroblasts in a fibromyxoid background $(\mathrm{H} \& \mathrm{E}, 20 \mathrm{x})$

There were six cases of GCT tendon sheath involving extremity (fingers of hand) and all of them occurred in males. There was only one case of benign fibrous histiocytoma which occurred in a 35 year old female on the extremity. (Table 5c) Microscopically GCT tendon sheath were characterized by variable the proportion of mononuclear cells, multinucleate giant cells, foamy macrophages, siderophages in fibrous stroma. Benign fibrous histiocytoma consists of cytologically bland spindled cells arranged in prominent storiform pattern, combined with haemangiopericytoma-like areas. 
Research Article

Table-5 (c): Age, gender, site and histological subtypes of fibrohistiocytic tumors.

\begin{tabular}{|c|c|c|c|c|c|}
\hline Sl. No. & Histological type & $\begin{array}{c}\text { No. of cases } \\
(\% \text { of benign tumors) }\end{array}$ & $\begin{array}{c}\text { Age in yrs } \\
\text { (Range) }\end{array}$ & Sex M/F & Common site \\
\hline 1. & GCT tendon sheath & $6(2.8 \%)$ & $20-52$ & $6 /--$ & $\begin{array}{c}\text { Extremity (fingers or } \\
\text { hand) }\end{array}$ \\
\hline 2. & $\begin{array}{c}\text { Benign fibrous } \\
\text { histiocytoma }\end{array}$ & $1(0.5 \%)$ & 35 & $--/ 1$ & Extremity \\
\hline & Total & $\mathbf{7 ( 3 . 3 \% )}$ & & $\mathbf{6 / 1 ( 6 : 1 )}$ & \\
\hline
\end{tabular}

Five cases $(2.3 \%)$ of extrauterine leiomyomas have been documented occurring in young adults all among females with equal predilection to trunk and extremities. Microscopically leiomyomas were characterized by whorls and interlacing fascicles of bland spindle shaped cells with areas of myxoid change. Benign vascular tumors were the second common tumor group (65 cases, 26\%). Capillary hemangiomas were more common than cavernous hemangiomas. Most of the hemangiomas occurred in the first two decades, thus accounting for the commonest benign soft tissue tumor of childhood. They showed a striking predilection for the head and neck region (most commonly over the lips) unlike other benign soft tissue tumors. (Table 5d)

Table-5 (d): Age, gender, site and histological subtypes of vascular tumors.

\begin{tabular}{|c|c|c|c|c|c|}
\hline Sl. No. & Histological type & $\begin{array}{c}\text { No. of cases (\% of } \\
\text { benign tumors) }\end{array}$ & $\begin{array}{c}\text { Age in yrs } \\
\text { (Range) }\end{array}$ & $\begin{array}{c}\text { Sex } \\
\mathbf{M} / \mathbf{F}\end{array}$ & Common site \\
\hline 1. & Capillary hemangioma & $28(13.1 \%)$ & $2-89$ & $20 / 8$ & Head and neck \\
\hline 2. & Cavernous hemangioma & $15(7.1 \%)$ & $4-57$ & $10 / 5$ & Head and neck \\
\hline 3. & Pyogenic granuloma & $7(3.3 \%)$ & $1-70$ & $3 / 4$ & Head and neck \\
\hline 4. & Venous hemangioma & $1(0.5 \%)$ & 46 & $1 /--$ & Extremities \\
\hline 5. & $\begin{array}{c}\text { Intramuscular } \\
\text { hemangioma }\end{array}$ & $2(0.9 \%)$ & $9-20$ & $2 /--$ & $\begin{array}{c}\text { Head and } \\
\text { extremities }\end{array}$ \\
\hline 6. & Lymphangioma & $11(5.2 \%)$ & $2-63$ & $4 / 7$ & Trunk and head \\
\hline 7. & Angiomatosis & $1(0.5 \%)$ & 16 & $--/ 1$ & Head and neck \\
\hline & Total & $\mathbf{6 5}(\mathbf{3 0 . 5 \% )}$ & & $\mathbf{4 0 / 2 5}$ & $\mathbf{( 1 . 6 : 1 )}$ \\
\hline
\end{tabular}

Microscopically capillary hemangioma consisted of small vessels lined by flattened mature endothelium. Cavernous hemangoima showed cavernous blood spaces separated by scant fibrous tissue. Pyogenic granuloma were characterized by lobules of small vessels with areas of stromal edema and mixed inflammatory cells. Lymphangioma showed dilated lymphatic channels lined by single layer of endothelial cells without atypia. One case of glomus tumor at the knee joint in 51 year old male was reported. Microscopically glomus tumor showed small uniform round cells surrounding blood vessels of varying sizes.

Neural tumors accounted for third most common benign soft tissue tumors. Neurofibroma predominantly occurred in females at the extremities whereas neurilemmoma was seen more commonly in males with the common site being head and neck. (Table 5e) Microscopically schwannomas were characterized by fascicles and whorls of spindle cells showing nuclear palisading with mild atypia. [Figure 2] Neurofibromas showed interlacing bundles of elongated cells with wavy, darkly-stained nuclei. The cells are intimately associated with wire-like strands of collagen stroma. The tumor was dotted with mast cells, lymphocytes, and few xanthoma cells.

Table-5 (e): Neural tumors

\begin{tabular}{|c|c|c|c|c|c|}
\hline Sl. No. & Histological type & $\begin{array}{c}\text { No. of cases (\% of } \\
\text { benign tumors) }\end{array}$ & $\begin{array}{c}\text { Age in yrs } \\
\text { (Range) }\end{array}$ & $\begin{array}{c}\text { Sex } \\
\text { M/F }\end{array}$ & Common site \\
\hline 1. & Schwannoma & $25(11.7 \%)$ & $14-7$ & $13 / 12$ & Head and neck \\
\hline 2. & Neurofibroma & $18(8.5 \%)$ & $15-61$ & $8 / 10$ & Extremity \\
\hline & Total & $\mathbf{4 3 ( 2 0 . 3 \% )}$ & & $\mathbf{2 1 / 2 2} \mathbf{1 : 1 . 0 5}$ & \\
\hline
\end{tabular}


Research Article
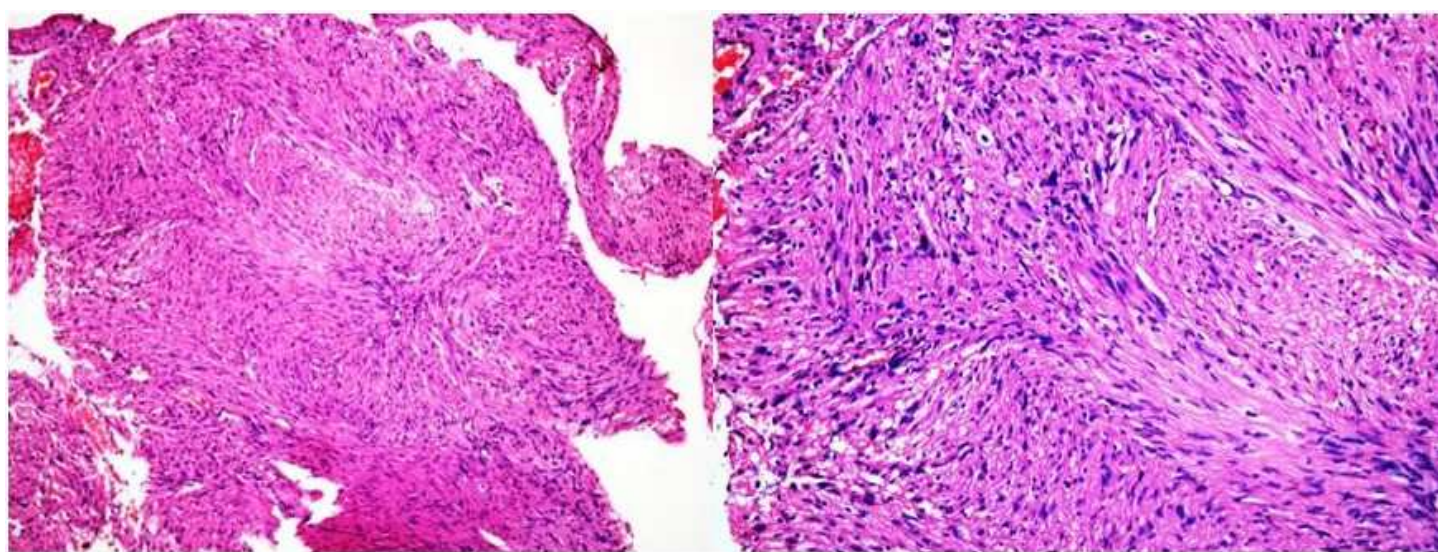

Fig 2a: Schwannoma- Fascicles and whorls of spindle cells (H \& E, 10x); Fig 2b: Spindle cells showing nuclear palisading with mild atypia (H \& E, 20x).

Three cases of tumors of uncertain differentiation were encountered in the present study of different histological types, most commonly occurring in middle adulthood all among females. (Table 6) Intramuscular myxoma occurred in 65 yearold-female in gluteus region. Microscopically intramuscular myxoma showed bland spindle cells separated by abundant extracellular myxoid matrix infiltrating surrounding skeletal muscles. Aggressive angiomyxoma was seen in 49 year-old female patient presenting as vulvar mass with grey white gelatinous appearance on cut section. Microscopically tumor showed evenly distributed spindle-shaped cells in a myxoid stroma with interspersed prominent vessels [Figure 3].

Table-6: Age, gender, site and histological type of tumors of uncertain differentiation

\begin{tabular}{|c|c|c|c|c|c|}
\hline Sl. No. & Histological type & $\begin{array}{c}\text { No. of cases (\% of } \\
\text { benign tumors) }\end{array}$ & $\begin{array}{c}\text { Age in yrs } \\
\text { (Range) }\end{array}$ & $\begin{array}{c}\text { Sex } \\
\mathbf{M} / \mathbf{F}\end{array}$ & Common site \\
\hline 1. & Intramuscular myxoma & 1 & 65 & $--/ 1$ & Gluteus \\
\hline 2. & Aggressive angiomyxoma & 1 & 49 & $--/ 1$ & Vulva \\
\hline 3. & Granular cell tumor & 1 & 40 & $--/ 1$ & Thigh \\
\hline & Total & $\mathbf{3 / 1 . 4 \% )}$ & & $--/ 3$ & \\
\hline
\end{tabular}
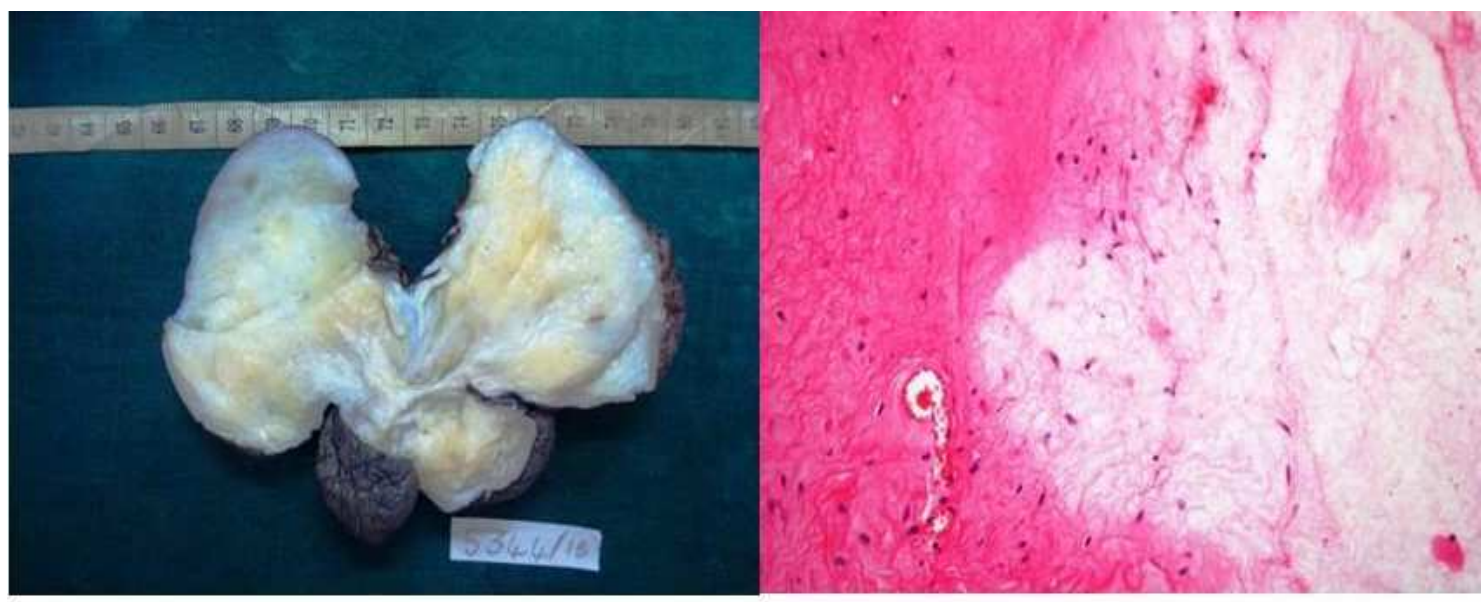

Fig 3(a): Aggressive angiomyxoma on cut-section showing glistening, homogenous, gelatinous appearance of polypoidal mass; Fig 3(b): Spindle-shaped cells with prominent vessels in a rich myxoid stroma.

Granular cell tumor was encountered in 40 year old female, presenting as thigh mass. Microscopically they were characterized by sheets of tumor cells separated by thin fibrous septae. Individual tumor cells were polygonal with abundant granular eosinophilic cytoplasm and small dark nuclei [Figure 4]. 


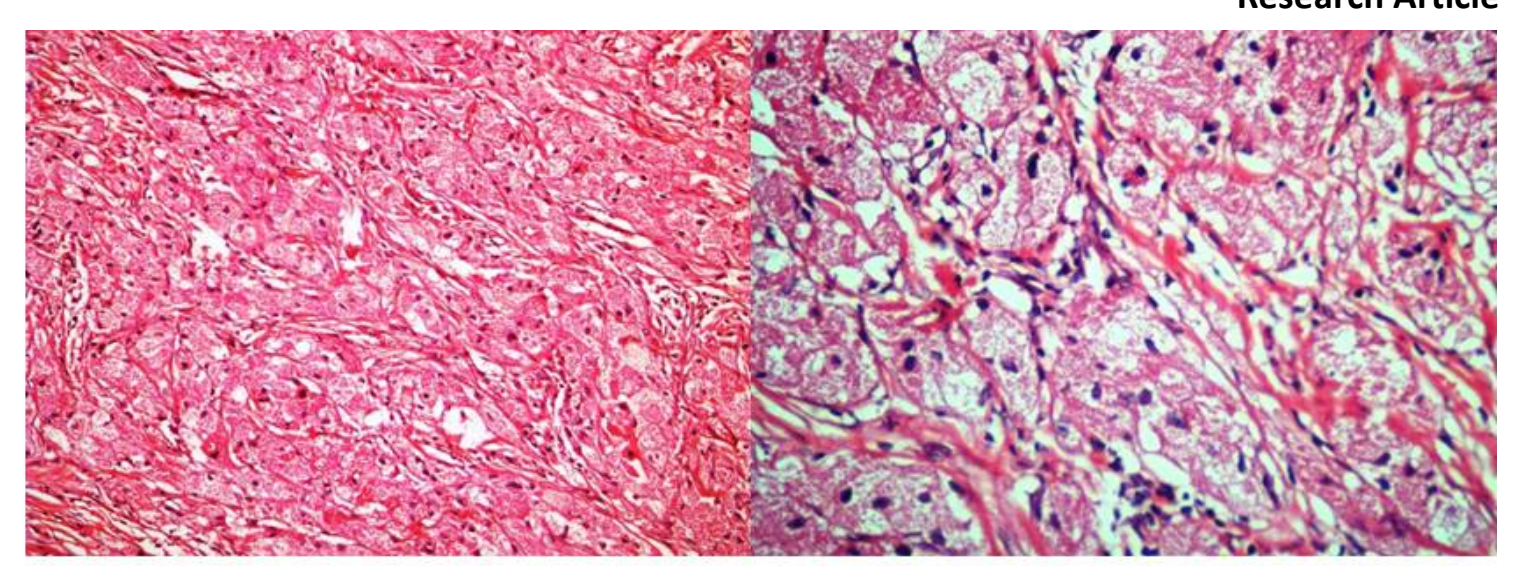

Fig 4a: Granular cell tumor- Sheets of tumor cells separated by thin fibrous septae (H \& E, 20x); Fig 4b: Polygonal cells with abundant granular cytoplasm and small dark nuclei $(\mathrm{H} \& \mathrm{E}, 40 \mathrm{x})$.

Majority of patients with benign soft tissue tumors underwent simple excision. Wide margin excision was performed for intramuscular myxoma due to its propensity for local recurrence. Aggressive angiomyxoma was treated by wide surgical resection with preservation of surrounding structures and lifetime follow up was advised to monitor for recurrence and metastasis [10].

\section{Discussion}

In the present study the age ranged from 4 months to 89 years. The average age in the case of benign tumors was 40 years which is comparable to the studies of Jensen OM [11]. The age range in the benign tumor group was 2 years to 89 years with a peak incidence in the third decade. In the case of benign tumor group there were 122 males and 91 females with a male to female ratio of 1.4:1 in contrast to the study of Jensen OM where the male to female ratio was 0.9:1 as outlined in Table 7 .

In the present study, the commonest site was the head and neck, in which is study comparable to the study of Dev $\mathrm{G}$ et al. This is in contrast to the study of Kransdorf MJ where the commonest site was upper extremity $[12,13]$.

The commonest benign tumor type was the adipose tumor forming $35.2 \%$ of benign soft tissue tumors, which is comparable to the studies of Jensen OM and Dev $G$ et al where they constituted $48.1 \%$ and $31.3 \%$ of benign tumors respectively $[11,12]$. The second most common benign tumor group was the vascular tumors, which constituted $30.5 \%$, which is comparable to the studies of Jensen OM and Kransdorf MJ where they formed $13.6 \%$ and $16.7 \%$ respectively $[11,13]$.

The benign fibrous tumors constituted $6.6 \%$ of all benign tumors, of which there were five cases of fibroma, which occurred in age group of 33-80 years. The commonest site was trunk comparable to the studies of other authors. There was one case of proliferative fasciitis $(0.5 \%)$ and proliferative myositis
(0.5\%), comparable to Kransdorf MJ study where they formed $0.8 \%$ and $0.3 \%$ respectively [13].

There were 65 cases of benign vascular tumors, commonest being capillary hemangioma accounting for $13.1 \%$, and a striking predilection for the head and neck region, which favourably compares with the studies of other authors.

There were 43 cases of benign neural tumors with slight female preponderance comparable to the study of Jensen OM. Commonest site was head and neck similar to the study of Kransdorf MJ [11,13].

There were three cases of tumors of uncertain differentiation all of them occurring in females with predilection to hip and buttocks. This is in contrast to studies of Jensen $\mathrm{OM}$ and Kransdorf MJ where the common sites were trunk and lower extremity respectively, with female preponderance $[11,13]$. In the study carried out by Jingping et al, the most common sites for aggressive angiomyxoma were the perineum in females which is comparable with our present study [14].

\section{Conclusion}

The large majority of soft tissue tumors are benign with a very high cure rate after surgical excision. Aggressive benign myxoid soft tissue tumors require wide surgical excision and close follow up. The diagnosis and management of benign soft tissue tumors require a team 
perspective consisting of clinical, radiological and pathological correlation. With our study, we were able to assess a hospital based data of various types of benign soft tissue tumors, their relative incidence, and their distribution with respect to the profile of the patient.

Funding: Nil, Conflict of interest: None initiated, Permission from IRB: Yes

\section{References}

1. General Considerations. Chapter 1 In: Weiss SW, Goldblum JR, editors. Enzinger and Weiss's Soft Tissue Tumors. $4^{\text {th }}$ ed. St. Louis: Mosby Publishing; 2001.

2. Randall RL. Approach to the diagnosis of bone and soft tissue tumors - Clinical, radiologic, and classification aspects. In: Folpe AL, Inwards CY, editors. Bone and Soft Tissue Pathology. 1st ed. Philadelphia: Saunders/Elsevier Publishing; 2010.

3. Rydholm A. Management of patients with soft-tissue tumors. Strategy developed at a regional oncology center. Acta Orthop Scand Suppl. 1983;203:13-77.

4. Rydholm A, Berg NO, Gullberg B et al. Epidemiology of soft tissue sarcoma in the locomotor system: A retrospective population based study of the inter-relationships between clinical and morphologic variables. ActaPathol Microbial Immunol Scand. 1984;92:363-74.

5. Agravat AH, Dhruva GA, Parmar SA. Histopathology study of human's soft tissue tumours and tumour like lesions. J Cell Tissue Research. 2010;10(2):2287-92.

6. Ramnani BG, Kumar A, Chandak S, Ranjan A, Patel MK. Clinicopathological profile of benign soft tissue tumours: a study in a tertiary care hospital in Western India. J Clin Diagn Res. 2014 Oct;8(10):FC01-4. doi: 10.7860/JCDR/2014/8690.4918. Epub 2014 Oct 20.

7. Rosenberg AE. Bones, joints and soft tissue tumors. In: Kumar V, Abbas AK, Fausto N, Aster JC, editors. Robbins and Cotran Pathologic Basis of Disease. $8^{\text {th }}$ ed. Philadelphia: Elsevier; 2010.

8. Allen PW. The diagnosis, classification and grading of soft tissue tumors. J Orthop Sci.1996;1:148-56.

9. Fletcher C.D.M., Unni K.K., Mertens F. (Eds.): World Health Organization Classification of Tumors. Pathology and genetics of tumors of soft tissue and bone. IARC Press:Lyon 2002.

10. Kura MM, Jindal SR, Khemani UN. Aggressive angiomyxoma of the vulva: An uncommon entity. Indian Dermatol Online J. 2012 May;3(2):128-30. doi: 10.4103/2229-5178.96712.

11. Myhre-Jensen O. A consecutive 7-year series of 1331 benign soft tissue tumours. Clinicopathologic data. Comparison with sarcomas. Acta Orthop Scand. 1981 Jun;52(3):287-93.

12. Dev G, Banerjee AK, Aikat BK. Soft tissue tumours. I. Benign tumours. Indian J Cancer. 1974 Sep; 11(3):336-43.

13. Kransdorf MJ. Benign soft-tissue tumors in a large referral population: Distribution of specific diagnosis by age, sex and location. AJR. 1995;164:395-402.

14. Jingping, Zhang, Chunfu Z. Clinical Experiences on Aggressive Angiomyxoma in China (Report of 93 Cases). International Journal of Gynecological Cancer. 2010;20(2):303-07.

\section{How to cite this article?}

Deepak MB, Suchitha S, Manjunath GV, Ira Bharadwaj. Clinico-pathological study of benign soft tissue tumors: a study from tertiary teaching hospital.Trop J Path Micro 2016;2(3):134-141.doi: 10.17511/jopm.2016.i03.09 